\title{
Presence of eubacteria in biopsies from Crohn's disease inflammatory lesions as determined by $16 S$ rRNA gene-based PCR.
}

\author{
ANNIKA TIVELJUNG, JOHAN D SÖDERHOLM*, GUNNAR OLAISON*, JON JONASSON and \\ HANS-JÜRG MONSTEIN
}

Department of Clinical Microbiology, Molecular Biology Laboratory, LMÖ, and *Department of Surgery, University Hospital of Linköping, S-581 85 Linköping, Sweden.

\begin{abstract}
The aim of this study was to search for putative microbial agents in Crohn's disease (CD) tissues by bacterial broad-range 16S rDNA PCR combined with genus- and species-specific DNA hybridisation analysis. Biopsies taken both surgically and endoscopically from the terminal ileum of $11 \mathrm{CD}$ patients and 11 control patients were investigated. Significant amounts of eubacteria were demonstrated in biopsies taken endoscopically from both affected and unaffected individuals; the biopsies taken at surgery from control patients were negative. Three of five biopsies taken surgically from CD patients harboured Helicobacter spp.-, Mycobacterium paratuberculosis-, Listeria monocytogenes- and Escherichia coli-like 16S rDNA sequences. These findings show the importance of the sampling method chosen when combined with molecular typing of eubacteria in intestinal tissues. The mixed bacterial flora found in the surgical biopsies from CD patients supports the idea that the enteric microflora enters primary lesions where secondary bacterial colonisers may elicit a chronic inflammatory syndrome.
\end{abstract}

\section{Introduction}

Crohn's disease (CD) is a chronic inflammatory bowel disease of unknown origin. The possibility of a microorganism causing the disease was raised in 1913 by Dalziel [1] and again in 1932 by Crohn et al. [2]. Bacteria from the gut lumen seem to be important in the development of mucosal inflammation in CD patients [3-5]. The two main hypotheses on $C D$ pathogenesis focus on whether (i) the enteric microflora is responsible for $\mathrm{CD}$ by acting as a persistent antigenic stimulus in genetically susceptible hosts [6], or (ii) that there is an as yet unidentified, specific microbial causation of CD [7]. Several investigators have sought evidence for a specific infectious agent of $\mathrm{CD}$ by various techniques. Mainly because of the occasional occurrence of sarcoid-like granulomas and the similarity of CD to Johne's disease in cattle, Mycobacterium paratuberculosis has been investigated as an infectious cause of $\mathrm{CD}$, but results have been conflicting and no convincing data have so far been presented [8-11]. Other bacteria and bacterial antigens have also been

Received 19 Feb. 1998; revised version received 17 July 1998; accepted 27 Aug. 1998.

Corresponding author: Dr H-J. Monstein. suggested as putative agents causing CD [12-16]. To date, there is no convincing evidence of an aetiological role for any specific bacteria in CD. The need for new approaches to detect and characterise bacteria in $\mathrm{CD}$ inflammatory lesions, e.g., by means of techniques used in molecular biology, seems evident.

The aim of this study was to identify and characterise the microbial flora in endoscopic and surgical biopsies from the terminal ileum of patients with $\mathrm{CD}$ and in patients with no inflammatory bowel disease. Based on the 16S rRNA genes, bacterial broad-range PCR amplification procedures were recently established [17] which enabled Relman and co-workers [18] to detect bacteria causing Whipple's disease in human biopsy specimens without the need for cultivating them. The present study used 16S rRNA gene PCR amplification, partial DNA sequence analysis and species-specific DNA hybridisation analysis $[19,20]$.

\section{Materials and methods}

\section{Patients and biopsies}

Ileal mucosal biopsies were obtained from 11 patients with Crohn's disease (CD) and 11 control patients (patient data are summarised in Table 1). None of the 
Table 1. Characteristics of the 11 patients with $C D$ and the 11 control patients

\begin{tabular}{lcc}
\hline Characteristics & CD patients & Control patients \\
\hline Age; median (range) & $36(16-49)$ & $50(22-73)$ \\
Sex (M/F) & $8 / 3$ & $7 / 4$ \\
Diagnosis & $\ldots$ & 3 \\
$\quad$ Ulcerative colitis & $\ldots$ & 3 \\
$\quad$ Colon cancer & $\ldots$ & 2 \\
$\quad$ Colon polyps & $\ldots$ & 3 \\
$\quad$ Functional bowel disorder & & \\
Previous bowel resection & $8 / 3$ & $4 / 7$ \\
$\quad$ (yes/no) & 7 & $\ldots$ \\
Location of CD & \multicolumn{2}{c}{} \\
$\quad$ lleocaecal or ileal & 4 & $\ldots$ \\
$\quad$ Colitis & $290(0-520)$ & $\ldots$ \\
CDAI median (range) & & $\ldots$ \\
\hline
\end{tabular}

${ }^{*}$ Disease activity was assessed by Best's modification of his classical $\mathrm{CD}$ activity index (CDAI). A CDAI $<150$ is considered as inactive disease [21].

patients was on antibiotic treatment, but all patients undergoing bowel surgery received prophylactic antibiotics (doxycycline and metronidazole i.v.) immediately before the start of the operation. Endoscopic biopsies (six CD patients, four control patients) were taken with standard forceps through a colonoscope. Surgical biopsies (five CD patients, seven control patients) were taken at bowel surgery, with biopsy forceps introduced directly into the ileal lumen. In the endoscopic biopsies the mucosa was inflamed in five of six CD patients. Surgical biopsies were obtained from inflamed or ulcerated mucosa from all five $\mathrm{CD}$ patients and, in addition, non-inflamed biopsies were obtained from three of these patients. All biopsies from the control patients were taken from macroscopically normal mucosa. The biopsies were throughly rinsed in $\mathrm{NaCl} 0.9 \%$ and then frozen immediately in liquid nitrogen and stored at $-70^{\circ} \mathrm{C}$ until DNA extraction for PCR.

\section{Bacterial strains}

Helicobacter pylori CCUG $17874^{\mathrm{T}}$ (Culture Collection of the University of Gothenberg, Sweden) was used as a reference strain in this study.

\section{Preparation of samples for PCR amplification}

Bacterial genomic DNA from the reference type strain H. pylori CCUG $17874^{\mathrm{T}}$ was extracted as described previously [19]. DNA from the human biopsy specimens was prepared with the Trizol-reagent (Gibco BRL, Life Technologies AB, Sweden). The extraction procedure followed the manufacturer's recommendations. Briefly, biopsy specimens (c. $5 \mathrm{mg}$ ) were mechanically homogenised with a Polytron (Kinematica, Littau/Luzern, Switzerland) in $0.5 \mathrm{ml}$ of phenol-based Trizol-reagent. The homogenate was mixed with chloroform and, after centrifugation, RNA was precipitated from the water phase with isopropanol, as recommended. DNA was recovered from the phenol phase after ethanol precipitation. DNA concentration and purity were measured spectrophotometrically at $\mathrm{OD}_{260 / 280}$. Extraction procedures were performed twice.

To exclude any possible contamination from the homogeniser, negative extraction controls were run in parallel and examined by PCR and Southern blot analysis.

\section{Oligonucleotides}

PCR primers were obtained from Pharmacia Biotech (Uppsala, Sweden). 16S broad-range bacterial primers pJB-1 (sense) and p13B (antisense) have been described previously [19]. Two Helicobacter-specific primers (HPV4 and HPV9) were designed from variable regions V4 and V9 within the 16S rRNA gene (nomenclature according to Gray et al. [22]). Primers HPV4 and HPV9 were subsequently used in DNA hybridisation analysis and DNA sequence analysis of PCR-amplified products (Table 2). Oligonucleotides for Southern blot analysis, complementary to variable regions V3, V4 of Escherichia coli, Chlamydia trachomatis, Enterococcus faecalis, Enterococcus spp., Listeria monocytogenes and M. paratuberculosis were obtained from Pharmacia Biotech and Life Technologies (Table 2).

Table 2. Oligonucleotide primers used in PCR amplification, Southern blot analysis and DNA sequence analysis

\begin{tabular}{|c|c|c|c|c|}
\hline \multirow{2}{*}{$\frac{\text { Oligonucleotide name }}{\text { pJB-1* }}$} & \multicolumn{2}{|c|}{ Start position } & \multirow{2}{*}{$\frac{\text { DNA sequence }\left(5^{\prime} \text { to } 3^{\prime} \text { orientation) }\right.}{\text { ATTCGATGCAACGCGAAGAACCTTACC }}$} & \multirow{2}{*}{$\begin{array}{c}\text { Accession number } \\
\text { Genebank/EMBL }\end{array}$} \\
\hline & $959^{\S}$ & $\rightarrow$ & & \\
\hline pl3B* & $1397^{\S}$ & $\leftarrow$ & GTGTACTAGGCCCGGGAACGTATTC & $\ldots$ \\
\hline $\mathrm{BR} 2 \mathrm{se}^{\dagger}$ & $970^{\S}$ & $\rightarrow$ & CGCGAAGAACCTTACCAGGTCTTGAC & $\ldots$ \\
\hline Helicobacter spp. (HPV9) ${ }^{\dagger}$ & $1226^{\|}$ & $\leftarrow$ & GCTTCTCTTTGTGCACCCCAT & M88157 \\
\hline Helicobacter spp. (HPV4) ${ }^{\ddagger}$ & $1142^{\|}$ & $\leftarrow$ & CCTCCTTACGGAGGCAGTATCCTT & M88157 \\
\hline L. monocytogenes ${ }^{\ddagger}$ & $1133^{\|}$ & $\rightarrow$ & CCAGCATTTAGTTGGGCACTC & X56153 \\
\hline M. paratuberculosis ${ }^{*}$ & $1082^{\|}$ & $\rightarrow$ & GGGTAATGCCGGGGACTCG & X52934 \\
\hline Ent. faecalis f $^{\ddagger}$ & $282^{\|}$ & $\leftarrow$ & TGCATGACCTCGCGGTC & Y12905 \\
\hline Enterococcus spp. & $282^{\|}$ & $\leftarrow$ & AGCTTAGCCTCGCGACT & Y12906 \\
\hline E. $\operatorname{coli}^{*}$ & 988 & $\rightarrow$ & CCACGGAAGTTTTCAGAGATGAG & $\mathrm{X} 80724$ \\
\hline C. trachomatis ${ }^{\ddagger}$ & 1033 & $\rightarrow$ & CGTTTTCCGCAAGGACATAT & M59178 \\
\hline
\end{tabular}

$\rightarrow$ sense; $\leftarrow$ antisense direction of PCR primers, DNA sequence primers and DNA hybridisation probes.

*PCR amplification primer.

†DNA sequencing primers.

${ }^{\ddagger}$ DNA hybridisation probes.

\$ Positions according to Gray et al. [22].

"Positions according to referred accession numbers. 


\section{PCR conditions}

Amplifications were performed as described in detail elsewhere $[19,20]$, with a PTC-100 Thermal Cycler (SDS Promega, Falkenberg, Sweden) and AmpliTaq Gold (Boehringer-Mannheim GmbH, Germany). In brief, $c .100 \mathrm{ng}$ of DNA were used for the bacterial broad-range 16S rDNA amplification. PCR cycle conditions were as follows: activation of AmpliTaq Gold at $94^{\circ} \mathrm{C}$ for $10 \mathrm{~min}$, denaturation at $94^{\circ} \mathrm{C}$ for $30 \mathrm{~s}$, annealing at $55^{\circ} \mathrm{C}$ for $30 \mathrm{~s}$, extension at $72^{\circ} \mathrm{C}$ for $1 \mathrm{~min}$ and a final extension at $72^{\circ} \mathrm{C}$ for $10 \mathrm{~min}$. A total of 30 cycles was performed for bacterial broad-range $16 \mathrm{~S}$ rDNA amplification. Negative PCR controls, containing distilled water instead of DNA, were run in parallel.

\section{Southern blot analysis of PCR products}

The amplified PCR products were analysed by agarose gel electrophoresis, Southern blot and DNA sequence analysis. Samples $(7 \mu \mathrm{l})$ of PCR-amplified products were electrophoresed on an agarose $1.5 \%$ gel, stained with ethidium bromide and visualised under UV light. Furthermore, 16S rDNA PCR products were transferred to Hybond-N membranes (Amersham) and hybridised with pJB-1 to visualise the presence of broad-range amplicons. Multiple DNA hybridisations were performed with oligonucleotides complementary to variable sequences within the 16S rRNA genes of Helicobacter spp., E. coli, Ent. faecalis, Enterococcus spp., C. trachomatis, L. monocytogenes and $M$. paratuberculosis. Oligonucleotides were 5 '-end-labelled with $\left[\gamma_{-}{ }^{32} \mathrm{P}\right]$ dATP $(3000 \mathrm{Ci} / \mathrm{mmol}$; Amersham) and a 5 '-end-labelling kit (Boehringer-Mannheim $\mathrm{GmbH}$ ). Prehybridisations and hybridisations were performed in SEP-buffer $\left(0.5 \mathrm{M} \mathrm{Na}_{2} \mathrm{HPO}_{4}, \mathrm{pH} 7.2,1\right.$ mM EDTAsodium salt; SDS $7 \%$ ) at $50^{\circ} \mathrm{C}$ overnight. Filters were washed in $2 \times \mathrm{SSC} / \mathrm{SDS} 0.01 \%$ for $3 \times 20 \mathrm{~min}(2 \times$ SSC is $300 \mathrm{~mm} \mathrm{NaCl}, 30 \mathrm{~mm}$ sodium citrate). The post-hybridisation conditions were more stringent to filters hybridised with the $L$. monocytogenes probe $(1 \times \mathrm{SSC} / \mathrm{SDS} 0.01 \%$ for $30 \times 20 \mathrm{~min})$. After each post-hybridisation step, membranes were exposed to MP X-ray films (Amersham) at $-70^{\circ} \mathrm{C}$ for $48 \mathrm{~h}$ (pJB-1 hybridisations) or 5 days (genus- and species-specific hybridisations).

\section{DNA sequence analysis}

Broad-range 16S rDNA PCR products were directly sequenced with a commercially available DNA sequencing kit (Thermo Sequenase Cycle Sequencing kit; Amersham). Cycle parameters were as follows: 30 cycles of denaturation at $94^{\circ} \mathrm{C}$ for $30 \mathrm{~s}$, annealing at $55^{\circ} \mathrm{C}$ for $20 \mathrm{~s}$ and extension at $72^{\circ} \mathrm{C}$ for $60 \mathrm{~s}$. The general BR2se primer was used as DNA sequencing primer (Table 2). To characterise the Helicobacterpositive samples, the Helicobacter-specific primer HPV9 was used for DNA sequence analysis. X-ray films were subsequently analysed with a computerised film scanner (SciScan 500, United States Biochemical,
Amersham; Sun SPARCStation 5, Sun Microsystems $\mathrm{AB}$, Kista Sweden). Comparative DNA sequence analyses to DNA databanks (EMBL and GeneBank) were performed.

\section{Results and discussion}

\section{Bacterial broad-range $16 S$ rDNA PCR}

PCR analysis based on bacterial broad-range $16 \mathrm{~S}$ rDNA sequences combined with Southern blot analysis was performed to investigate the presence of eubacteria in intestinal biopsies from patients with CD. Different commercial taq polymerases were tested and AmpliTaq Gold (Boehringer-Mannheim) gave the most reproducible results (data not shown). Surgical biopsies were positive for bacteria in three of five patients with $C D$, but in none of seven control biopsies (Fig. 1). In contrast, nine of 10 endoscopic biopsies were positive for bacteria and there was no difference between patients with $\mathrm{CD}$ and control patients (five of six and four of four, respectively) (Fig. 1). This difference between surgical and endoscopic biopsies is noteworthy. Whilst it is clear that endoscopy per rectum involved a risk of contaminating the instrument, and hence the biopsy specimen, bacteriological findings are only relevant if the bacteria actually emanate from the biopsy. The results presented here demonstrate the importance of the biopsy sampling method chosen, as well as the level of sensitivity of the PCR method used. The biopsies taken by endoscopy were uniformly contaminated by the luminal microbial flora, while the control biopsies taken surgically were negative. Thus, to eliminate any false-positive results due to heavy luminal bacterial contamination, surgical resection is the method of choice for obtaining intestinal biopsies for PCR analysis.

\section{Southern blot analysis of the PCR products with regard to putative pathogens}

Southern blot analysis with selected numbers of genusor species-specific hybridisation probes directed against variable regions within the 16S rRNA genes to detect the presence of potential microbial pathogens in biopsy specimens was performed as described previously $[8,12,13]$. These hybridisation probes were designed from DNA sequences of Helicobacter spp., M. paratuberculosis, L. monocytogenes, E. coli, Ent. faecalis, Enterococcus spp. and C. trachomatis. A homology search in public databases revealed that these sequences are not unique to one species. For example, the E. coli hybridisation probe also targets Shigella, Salmonella and Klebsiella spp. There is obviously a risk of cross-hybridisation to other closely related bacteria.

The Southern blot analysis revealed a mixed bacterial flora in endoscopic biopsies from CD patients and controls, as summarised in Table 3 . The seven surgical 
a

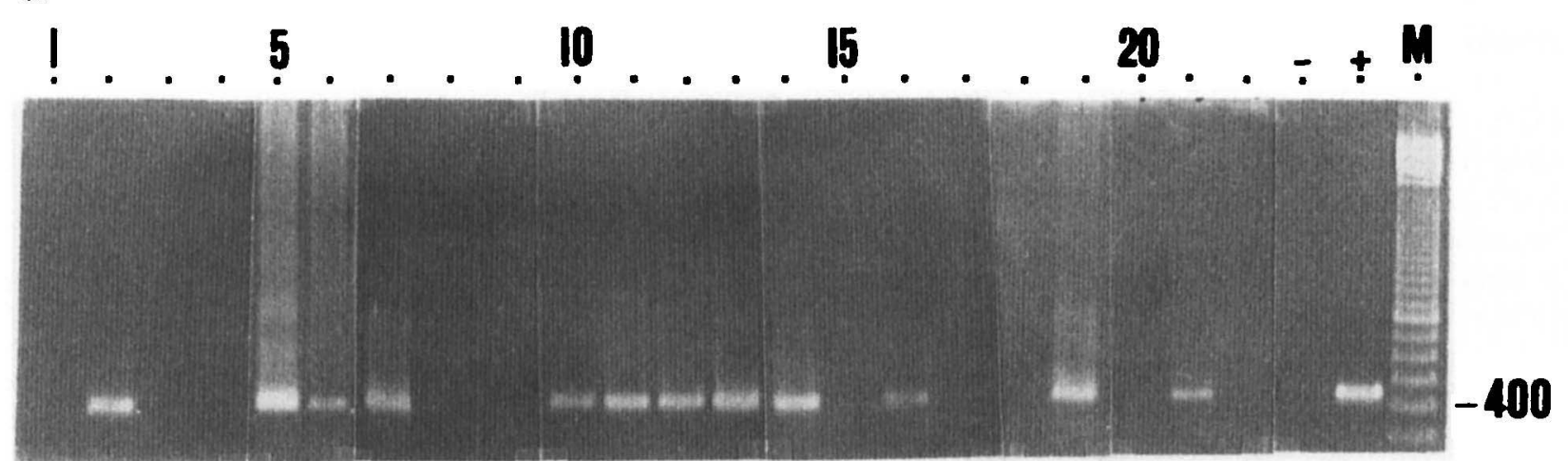

b

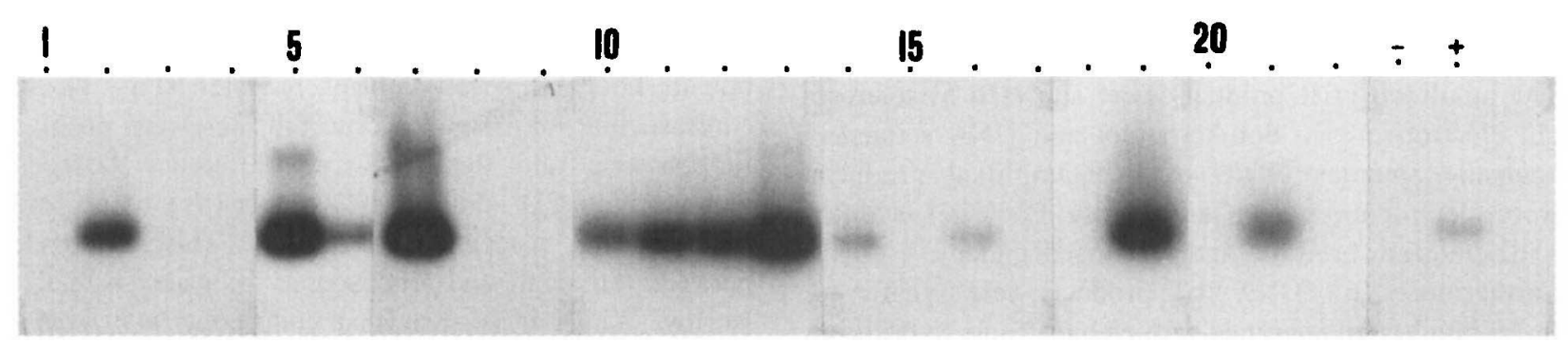

Fig. 1. Bacterial broad-range $16 \mathrm{~S}$ rRNA gene PCR-amplified products from biopsies of CD patients and controls. a, ethidium bromide-stained agarose gel; b, Southern blot analysis with the broad-range hybridisation probe pJB-1. Lanes $1,8,9,15,18,20,22$, normal control biopsies taken surgically; 2, 4, 10, 17, 21, CD biopsies taken surgically; 11, 12, 13, 16, normal control biopsies taken endoscopically; $3,5,6,7,14,19$, CD biopsies taken endoscopically. + , positive PCR control; -, negative PCR control; M, mol. wt marker (100 bp).

Table 3. Summarised results of bacterial broad-range, genus- and species-specific hybridisation analysis of $16 \mathrm{~S}$ rDNA PCR products

\begin{tabular}{|c|c|c|c|c|}
\hline \multirow[b]{2}{*}{ Organisms } & \multicolumn{2}{|c|}{ CD patient } & \multicolumn{2}{|c|}{ Control patients } \\
\hline & $\begin{array}{c}\text { endoscopic } \\
\text { biopsies (6) }\end{array}$ & $\begin{array}{c}\text { surgical } \\
\text { biopsies (5) }\end{array}$ & $\begin{array}{c}\text { endoscopic } \\
\text { biopsies (4) }\end{array}$ & $\begin{array}{c}\text { surgical } \\
\text { biopsies (7) }\end{array}$ \\
\hline pJB-1 (eubacteria)* & 5 & 3 & 4 & 0 \\
\hline Helicobacter* & 5 & 3 & 4 & 0 \\
\hline M. paratuberculosis* & 3 & 2 & 1 & 0 \\
\hline L. monocytogenes ${ }^{\dagger}$ & 5 & 3 & 4 & 0 \\
\hline E. coli $^{*}$ & 2 & 2 & 0 & 0 \\
\hline Ent. faecalis* & 0 & 0 & 0 & 0 \\
\hline Enterococcus spp.* & 1 & 0 & 0 & 0 \\
\hline C. trachomatis ${ }^{*}$ & 0 & 0 & 0 & 0 \\
\hline
\end{tabular}

Genus- and species-specific hybridisation probes as described in Table 2.

${ }^{*}$ Post-hybridisation conditions: $2 \times \mathrm{SSC} / \mathrm{SDS} 0.1 \% / 50^{\circ} \mathrm{C}$ repeated $3 \times 20 \mathrm{~min}$. The films were exposed at $-70^{\circ} \mathrm{C}$ for 5 days.

${ }^{\dagger}$ Post-hybridisation conditions: $1 \times \mathrm{SSC} / \mathrm{SDS} 0.1 \% / 50^{\circ} \mathrm{C}$ repeated $3 \times 20 \mathrm{~min}$. The films were exposed at $-70^{\circ} \mathrm{C}$ for 5 days.

control biopsies gave negative results, as did the three non-inflamed surgical biopsies from $C D$ patients. The surgical biopsies representing inflamed or ulcerated mucosa from three of five $\mathrm{CD}$ patients harboured Helicobacter spp.-, Listeria spp.-, Mycobacterium spp.-, and $E$. coli-like DNA sequences. The simultaneous positivity for DNA of different bacteria in three of five surgically resected $C D$ inflammatory lesions suggests that the bacteria may be secondary invaders, presumably constituents of the local enteric microflora. Although Oberhuber and co-workers have shown that there is a negative correlation between Helicobacter infection and gastric CD [16], the presence of Helicobacter spp. DNA in endoscopic biopsies was not surprising. A recent study demonstrated that Helicobacter spp. may be present in the human gut far more frequently than previously believed, without causing gastritis or eliciting an immune response [23]. $M$. paratuberculosis and $L$. monocytogenes are both facultative intracellular bacteria that have been implicated as putative pathogens in $C D[8,13]$. These bacteria are widely distributed in 
the environment and have many opportunities to enter the gut via contaminated food. The present data suggest that carriage rates are much higher than generally appreciated. DNA sequences complementary to the $E$. coli hybridisation probe were also found among endoscopic and surgical biopsies from $C D$ patients and from endoscopic control biopsies (Table 3). The Ent. faecalis hybridisation probe did not yield any signals, while one endoscopic biopsy from a CD patient reacted with the Enterococcus spp. probe, which targets a number of Enterococcus spp. other than Ent. faecalis, as described recently [24]. No $C$. trachomatis-specific 16S rRNA gene PCR products were found in the intestinal tissues (Table 3).

\section{$D N A$ sequence analysis of $P C R$ products}

The colon and distal ileum contain high concentrations of predominantly anaerobic bacteria. Antibiotic trials have indicated that anaerobic bacteria may have a role in $C D$ [25], but so far no putative CD-inducing anaerobe has been identified. Probes that would hybridise with DNA from anaerobic normal flora were not included in the present study. To investigate whether a bacterium not represented by the hybridisation probes was present in all specimens, the bacterial broad-range $16 \mathrm{~S}$ rDNA PCR amplified products were DNA sequenced by a semi-nested approach, with BR2se used as sequencing primer. This revealed a heterogeneous DNA sequence pattern in the variable regions V3 and V4 [22], which is indicative of the simultaneous presence of different kinds of bacteria with no one predominant (Fig. 2). Homology searches in public databases (NCBI BLAST) were perfomed to evaluate the mixed DNA sequence patterns. In the specific case illustrated in Fig. 2 (endoscopic biopsy from a CD patient), a predominant pattern compatible with Clostridium spp. or Ruminococcus spp. and other gram-positive bacteria was found. Another endoscopic biopsy from the $\mathrm{CD}$ patient group showed a similar Clostridium spp.-like pattern, whereas the third analysable sample showed a pattern found predominantly in gram-negative aerobic enterobacteria represented by $E$. coli/Salmonella spp./Shigella spp. 16S rDNA. However, the remaining two endoscopic biopsies in this group and all 16S rDNA sequences from endoscopic control biopsies were impossible to analyse because DNA sequence patterns were too complex, i.e., a mixed microflora of strains containing unequal numbers of nucleotides in their variable regions V3 or V4 so that the constant regions in between were out of phase. For example, a mixture of $E$. coli and Bacteroides spp. would be expected to display such a pattern. In one of the surgical biopsies from CD tissue, the Ruminococcus. spp./Clostridium spp. pattern was dominant, but in the two other biopsies (which were also positive by hybridisation with the $E$. coli probe) (Table 3) the $E$. coli/Salmonella spp./Shigella spp. 16S rDNA pattern was found. The outcome of this analysis is obviously dependent on which $16 \mathrm{~S}$ rDNA sequences are present

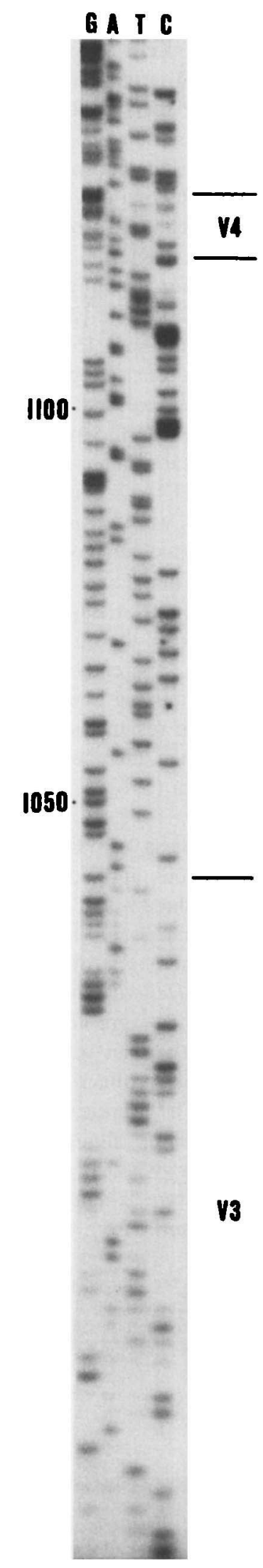

Fig. 2. Representative autoradiograph from DNA sequence analysis of the broad-range $16 \mathrm{~S}$ rRNA gene PCR-amplified product of a biopsy taken endoscopically from a $C D$ patient, visualising a mixed base pattern within variable regions $\mathrm{V} 3$ and $\mathrm{V} 4$, and the conserved DNA sequences in between. 
in the databases as well as the search algorithm. The present findings would seem to warrant further studies of the potential use of broad-range PCR and partial 16S rDNA sequencing for the characterisation of the enteric microflora. A refinement of this study would comprise 16S rDNA sequence analysis before DNA hybridisation probe construction, combined with more advanced separation techniques for the analysis of $16 \mathrm{~S}$ rDNA of the mixed bacterial flora found in the intestinal biopsies by, for example, DGGE (denaturing gradient gel electrophoresis) [26]. The interesting finding that Helicobacter spp. 16S rDNA was present in surgical resected biopsies (from three CD patients) may imply that Helicobacter spp. can act as ulcerative pathogens in $\mathrm{CD}$ as well as in gastritis. Attempts were also made to use the same material and Helicobacter spp.-specific internal DNA sequencing primer. However, these experiments were unsuccessful, presumably due to the presence of too few copies of Helicobacter spp. template DNA. This makes the possibility of a role of Helicobacter spp. as a single causative agent of CD seem unlikely. Instead, the mixed bacterial population observed here is apparently consistent with the idea that bacteria colonising the epithelia, inducing ulcers, eliciting immune responses and thereby causing chronic inflammation, are members of perhaps imbalanced enteric microflora $[5,6]$.

In summary, on the basis of PCR-based 16S rDNA molecular typing methods applied to intestinal biopsy specimens, it is concluded that the bacterial DNA found in CD lesions represents invasion of intestinal mucosa by several members of the resident flora. DNA sequences from Helicobacter spp., Listeria spp. and Mycobacterium spp. were found in mixed populations more frequently than anticipated. The technique used for specimen collection seemed to be of utmost importance. The surgical resection method allowed sampling without significant contamination from the luminal flora, whereas specimens taken by endoscopic methods were almost uniformly heavily contaminated with bacteria from the bowel.

This work was supported by the Molecular Biology Program, LMÖ and the Swedish Medical Research Council (K98-06X-12618-01A) A. T. was supported by a pre-doctoral fellowship from the Faculty of Health Science, University of Linköping, Sweden.

\section{References}

1. Dalziel TK. Chronic interstitial enteritis. $B M J$ 1913; 2: 1068-1070.

2. Crohn BB, Ginzburg L, Oppenheimer GD. Regional ileitis - a pathologic and clinical entity. JAMA 1932; 99: 1323-1329.

3. Rutgeerts P, Goboes K, Peeters M et al. Effect of faecal stream diversion on recurrence of Crohn's disease in the neoterminal ileum. Lancet 1991; 338: 771-774.

4. Olaison G, Smedh K, Sjödahl R. Recurrence of Crohn's disease in the neo-terminal ileum and colonic factors. Lancet 1991; 338: 1401.

5. Macpherson A, Khoo UY, Forgacs I, Philpott-Howard J, Bjarnason I. Mucosal antibodies in inflammatory bowel disease are directed against intestinal bacteria. Gut 1996; 38: 365-375.
6. Sartor RB. Enteric microflora in IBD: pathogens or commensals? Inflam Bowel Dis 1997; 3: 230-235.

7. Blaser MJ. Microbial causation of the chronic idiopathic inflammatory bowel diseases. Inflam Bowel Dis 1997; 3: $225-229$.

8. Chiodini RJ, van Kruiningen HJ, Merkal RS, Thayer WR, Coutu JA. Characterisitics of an unclassified Mycobacterium species isolated from patients with Crohn's disease. $J$ Clin Microbiol 1984; 20: 966-971.

9. Van Kruiningen HJ, Chiodini RJ, Thayer WR, Coutu JA, Merkal RS, Runnels PL. Experimental disease in infant goats induced by a Mycobacterium isolated from a patient with Crohn's disease. A preliminary report. Dig Dis Sci 1986; 31: $1351-1360$.

10. Sanderson JD, Moss MT, Tizard MLV, Hermon-Taylor J. Mycobacterium paratuberculosis DNA in Crohn's disease tissue. Gut 1992; 33: 890-896.

11. Rowbotham DS, Mapstone NP, Trejdosiewicz LK, Howdle PD, Quirke P. Mycobacterium paratuberculosis DNA not detected in Crohn's disease tissue by fluorescent polymerase chain reaction. Gut 1995; 37: 660-667.

12. Blaser MJ, Miller RA, Lacher J, Singleton JW. Patients with active Crohn's disease have elevated serum antibodies to antigens of seven enteric bacterial pathogens. Gastroenterology 1984; 87: 888-894.

13. Liu $\mathrm{Y}$, van Kruiningen HJ, West AB, Cartun RW, Cortot A, Colombel J-F. Immunocytochemical evidence of Listeria, Escherichia coli, and Streptococcus antigens in Crohn's disease. Gastroenterology 1995; 108: 1396-1404.

14. El-Omar E, Penman I, Cruikshank G et al. Low prevalence of Helicobacter pylori in inflammatory bowel disease: association with sulphasalazine. Gut 1994; 35: 1385-1388.

15. Halme L, Kärkkäinen P, Rautelin H, Kosunen TU, Sipponen P. High frequency of helicobacter negative gastritis in patients with Crohn's disease. Gut 1996; 38: 379-383.

16. Oberhuber G, Püspök A, Oesterreicher C et al. Focally enhanced gastritis: a frequent type of gastritis in patients with Crohn's disease. Gastroenterology 1997; 112: 698-706.

17. Chen K, Neimark H, Rumore P, Steinman CR. Broad range DNA probes for detecting and amplifying eubacterial nucleic acids. FEMS Microbiol Lett 1989; 57: 19-24.

18. Relman DA, Schmidt TM, MacDermott RP, Falkow S. Identification of the uncultured bacillus of Whipple's disease. $N$ Engl J Med 1992; 327: 293-301.

19. Tiveljung A, Backström J, Forsum U, Monstein H-J. Broadrange $\mathrm{PCR}$ amplification and DNA sequence analysis reveals variable motifs in 16S rRNA genes of Mobiluncus species APMIS 1995; 103: 755-763.

20. Monstein H-J, Kihlström E, Tiveljung A. Detection and identification of bacteria using in-house broad range $16 \mathrm{~S}$ rDNA PCR amplification and genus-specific DNA hybridization probes, located within variable regions of $16 \mathrm{~S}$ rRNA genes. APMIS 1996; 104: 451-458.

21. Best WR, Becktel JM. The Crohn's disease activity index as a clinical instrument. In: Peña A, Weterman IT, Booth CC, Strober W (eds) Recent advances in Crohn's disease. The Hague, Martinus Nijhoff. 1981: 7-12.

22. Gray MW, Sankoff D, Cedergren RJ. On the evolutionary descent of organisms and organelles: a global phylogeny based on a highly conserved structural core in small subunit ribosomal RNA. Nucleic Acids Res 1984; 12: 5837-5852.

23. Tiveljung A, Borch $\mathrm{K}$, Jonasson $\mathrm{J}$, Mărdh S, Petersson $\mathrm{F}$, Monstein H-J. Identification of Helicobacter in gastric biopsies by PCR based on 16S rDNA sequences: a matter of little significance for the prediction of $H$. pylori-associated gastritis? $J$ Med Microbiol 1998; 47: 695-704.

24. Monstein H-J, Quednau M, Samuelsson A, Ahrné S, Isaksson B, Jonasson J. Division of the genus Enterococcus into species groups using PCR-based molecular typing methods. Microbiology 1998; 144: 1171-1179.

25. Ursing B, Alm T, Bárány F, Bergelin I et al. A comparative study of metronidazole and sulfasalazine for active Crohn's disease: the Cooperative Crohn's Disease Study in Sweden. II. Remet. Gastroenterology 1982; 83: 550-562.

26. Muyzer G, de Waal EC, Uitterlinden AG. Profiling of complex microbial populations by denaturing gradient gel electrophoresis analysis of polymerase chain reaction-amplified genes coding for 16S rRNA. Appl Environ Microbiol 1993; 59: 695-700. 